\title{
Introduction to the special issue: Roman canals studies-main research aims
}

\author{
Ferréol Salomon • Louise Purdue • Jean-Philippe Goiran • \\ Jean-François Berger
}

Published online: 3 April 2014

(C) Springer Science+Business Media Dordrecht 2014

This special issue of Water History is the first of a set of two volumes dedicated to canals and their evolution through time. These two publications derive from a workshop organised at the Maison de l'Orient et de la Méditerranée in Lyon (France) under the sponsorship of the University of Lyon 2 and the CNRS, on the 23rd and 24th of May 2012, entitled "Diverting water... Canals through time: a technological answer to socio-environmental variability". The themes of the workshop focused on "canals" and addressed the question of long-term interactions between nature and society, as well as the organisation and regulation of hydrologic and anthropic systems through time.

This first volume focuses on a socio-cultural context: the ancient Roman world, i.e. an archetypical hydraulic society. The case studies developed are related to canals in environments characterized by complex interactions at different spatial and temporal scales (deltaic area, alluvial plain or mountains). They do not include urban water systems as the latter are too specific (water supply of the cities by aqueducts or the drain of waste water by sewers). The second volume will be structured around the issue of water management in

F. Salomon $(\bowtie)$

School of Humanities, Archaeology, University of Southampton, Avenue Campus,

Southampton SO17 1BF, UK

e-mail: ferreol.salomon@gmail.com

L. Purdue

UMR 7264 - CEPAM, Université de Nice Sophia Antipolis, Nice, France

e-mail: louise.purdue@cepam.cnrs.fr

J.-P. Goiran

CNRS UMR 5133 - Achéorient, Maison de l'Orient et de la Méditerranée, 7, Rue Raulin, 69007 Lyon,

France

e-mail: jean-philippe.goiran@mom.fr

J.-F. Berger

CNRS UMR 5600 - EVS-IRG, Université Lumière Lyon 2, 5, avenue Pierre Mendès France,

69676 Bron Cedex, France

e-mail: jean-francois.berger@univ-lyon2.fr 
arid and Mediterranean environments, where water availability represents more of a constraint.

We define a canal as an anthropic structure receiving and conveying concentrated water flow and deriving all or part of the water coming from a natural channel or from another water origin. The study of canals is understood primarily from a spatial point of view (referring to the terms of landscape, network or watershed) and in an interdisciplinary research context. As such it requires the integration of different approaches (photo-interpretation, archaeology, texts, ancient maps, geoarchaeology, geochronology, palaeobotany...). We would like to present in this introduction some key issues related to the study of canals during the Roman period and put the articles of this volume into perspective. We present first a state of the art in roman canals studies and highlight the large range of canals constructed in the Roman world. Afterwards, we emphasize the difficulties to locate and identify these canals. Once the roman canal identified with certainty, its structure and infill are studied in terms of construction/use/abandonment in order to appropriately discuss its function.

This special issue comprises five papers concerning sites located in the western part of the Roman Empire. The first two articles focus on the Tiber delta, around the ancient Roman harbour of Portus. The paper of Keay et al. provides new data using extending magnetic surveys around Portus and draws a landscape intensively excavated by canals with different functions (drainage, navigation or canals associated with saltworks). The second paper, written by Salomon et al. develops a multidisciplinary research, focussing on one of these canals, which was initially dedicated to navigation and was probably used as a harbour canal. This canal was precisely located by magnetic surveys, and its study provides a high resolution analysis of the sedimentary infill that allows the authors to reconstruct and understand its evolution through time. The third paper, written by de Kort et al. concerns another canal in a deltaic area. Located in the northern fringe of the Roman Empire (Limes Germanicus), this canal was excavated to allow navigation between the Rhine and Meuse Rivers. Evidence fits well with a canal excavated by the Roman general Corbulo, quoted by Tacitus (Ann., 11, 18-20) and Cassius Dio (Rom. Hist., LXI, 61, 30, 4-6). The fourth paper deals with a riverine and marshy plain of the Upper Rhône valley. The authors, Bernigaud et al. analyse gravity irrigation systems dedicated to watering meadows. They focus on the development of Roman hydraulic systems in connection with the urban expansion in the Northern Province of Gallia Narbonnensis. Based on numerous radiocarbon datings, they trace the development of hydraulic in the region back to several centuries, thanks to the identification of Gallic or even earlier canals (early Iron Age). The last article, by del Arbol Moro et al. presents a synthesis of archaeological studies undertook on the exploitation of Roman gold mines located in the northwestern Iberian Peninsula. The authors focus on the canal networks put in place by the $1 \mathrm{st} \mathrm{c}$. AD and their use for the extraction and the washing of ore. The authors emphasize the changes in the landscape morphology generated by these operations.

\section{Roman canals studies}

Canals can be considered as the basic structure of hydraulic systems. They are key elements for the understanding of broader issues: environmental change and human forcing (Berger 2008), socio- economic and political contexts for the emergence of complex societies (Uggeri 1997; Wilkinson 2013; Wilson 2012a, b), ancient know-hows and techniques (Moore 1950; Leveau 2006a). 
From Hadrian's Wall (Scotland) to the Middle East, Rome brought together different physiographic and bioclimatic regions associated with different types of landscapes (alluvial, lacustrine, coastal, mountainous...), in different climates (temperate continental or temperate oceanic, arid and Mediterranean). Different previous local practices were probably adapted and exposed to practices transmitted by Romanization. This resulted in a wide variety of canal designs, uses and functions from one period to another, from one place to another, from a local scale (the stretch of a canal) to the scale of a landscape or territory (a canal network).

Drainage ditches (Burnouf and Leveau 2004; Leveau 2007) and aqueducts (Ashby 1935 Hodge 2001) are two types of canals often associated with the Roman civilization, but they represent only a part of the hydraulic networks built during this period. Canals for irrigation, navigation or diversion canal for specific purposes, such as those related to mills or mining, are also characteristic of the Roman world. They have been largely neglected in previous publications, or simply drawn on maps alongside archaeological sites. Therefore, often, they have not been studied from a socio-environmental perspective.

Canals are anthropic structures dealing with hydrosedimentary fluxes controlled by socio-environmental processes. In this respect, they are specific research objects at the crossroads of historical, archaeological, landscape and paleoenvironmental studies. Like the study of ancient harbours (Goiran and Morhange 2003; Marriner and Morhange 2007; Keay 2013), canals are matters of interdisciplinary researches and discussions (Berger and Jung 1996; Berger 2000, 2008; Leveau 2006a; Bernigaud 2012; Salomon 2013).

\section{Identification of ancient roman canals}

There are different kind of canals and different states of preservation. The identification of a canal is sometimes unnecessary (e.g. in the case of the aqueduct of Pont du Gard), or can be in other cases almost inextricable (Rescanières 2002 for the Canal de la Robine near Narbonne). It is possible to deplore the lack of written sources preserved today from the Roman period. However, the information available through these texts allows us, under rigorous scientific work, to engage complex and creative thinking, and to limit speculation.

Ideally, identification of canals is possible through the analysis of archived data (aerial photographs, old maps, inscriptions or ancient texts, old publications etc.) and through fieldwork (archaeological and geophysical surveys, excavations and cores). However, even if the study area offers a large amount of archived data and the research fields are diversified, the identification of a canal can remain difficult. This complexity depends on the original structure of the canal and on the local post-depositional processes that affect the state of preservation and the burial of the canal. Three main questions should be raised when searching for hydraulic structures:

1. Is the alignment observed by aerial photography, geophysical survey or else, the evidence of a channel or an earthen path?

2. Is this feature a channel, a channelization or a canal?

3. Can the information provided by written archives be combined with field data?

These questions can be answered when taking into account: the canal in its context (location and topography of the site, orientation of the canals and their connections); its profile; the sedimentary deposits trapped inside the canal; dating; archaeological structures associated (docks, mill, mole of derivation, etc.) and texts. Every article in this special issue presents a different set of data. It is interesting to read how the arguments are 
constructed for each of the items that lead to the identification of a canal (we emphasise that the first two papers written by Keay et al. and Salomon et al. are related to a common research project).

It should be noticed that the study of written archives can sometimes lead to questions 1 and 2 as well. In his description of the Nile Delta, Herodotus mentions five natural mouths of the Nile and two artificial mouths called Bolbitine and Bucolic (The Histories II, 10 and 17). A question is asked rightly by Carrez-Maratray (2003): How could Herodotus know whether they are natural and artificial canals? (in case of rechanneling of the canals). No definitive answer is proposed by the author, but this point still remains an important keyquestion in our understanding of the Herodotus geography. Archaeologists and geoarchaeologists are also involved in this research and attempt to identify both previous Nile River channels and canals (Bietak 1975; Stanley and Warne 1993).

\section{What are the evolutions of canals through time?}

An important challenge is to place the canal, or the canal network, in its temporal frame. Each canal stretch has its own evolution that can be defined in a relative chronological framework including: (1) the excavation, the construction; (2) the functioning periods; and (3) the abandonment. Afterwards, these events have to be dated using absolute and relative dating (radiocarbon dating, dendrochronology, Optical Stimulated Luminescence, archaeological evidences, ceramics).

Expertise, planning, excavation and construction

The attempt to identify elements related to the initial phase of the canal is fundamental but brings out some problems of preservation in the field. In fact, natural processes (changes in energy flows and transported sediments) and successive man-made operations (including dredging and cleaning) modify the initial cross-section of the canal and may remove early stages of deposition. These problems appear to varying degrees in each of the case studies presented in this issue of Water History (uncertain dating of the first canals uses in Bernigaud et al. initial depth probably removed by floods that entered the Canale Romano in Salomon et al. complex chronology of canal networks in mines in northwestern Spain in Arbol Moro et al.). Using field data, researchers are often dealing with the difficulty of identifying the initial planning of a canal network. This is especially true for canal networks identified in the margins of the Roman world, very different from the classic models associated with Romanization. Thus, in these cases, it is easier to study changes and subsequent adaptations, or to study human-environment interactions within a specific landscape (e.g. Leveau 2006a and Mathieu et al. 2011, for mountain environments; Arnaud-Fassetta and Landuré 2003, Rousse 2005, Salomon 2013 for deltaic environments). Nevertheless, canal networks associated with urban structures (Rousse 2005; Vigoni 2006) or centuriations (Brigand 2010; Chouquer and Favory 1991) are without doubt governed by planning. Ancient texts clearly express the expertise and the planning involved (archives on Roman surveying are discussed in Chouquer and Favory 2001). Technology, knowhows and knowledge transfer play a very important part in the installation and the development of water networks, even in the margins of hydraulic empires. Their study raises questions about the modes of expression of the Romanization, its acceptance by local societies and the persistence of technical and cultural traditions (Leveau 2006a; Kamash 2012). 
Operation and maintenance

The use and life of a canal depend on 1-the natural adjustment of the canal network included in the river system (Berger 2008) and 2-the social, political and economic context. This can be expressed in terms of representation, adaptation/adjustment between both environmental changes and needs of societies (Van der Leeuw 2002; Lévêque et al. 2003; Berger 2008).

Natural adjustments, which impact canal shape and consequent longitudinal and transversal cross-section (following episodes of river incision, filling or lateral mobility), are controlled by changes in the hydrosedimentary flow. The latter responds to climate change and land use, which are discussed in detail in different parts of the Roman world (Bravard et al. 1992; Jorda 1992; Arnaud-Fassetta 1998; Allée and Lespez 2006; Berger and Bravard 2012).

Anthropogenic modifications are visible through canal maintenance (redesign, cleaning), modifications related to infrastructure (restoration of piers dedicated to water diversion...), or even in the addition of structures (lateral structures; transverse structures such as reservoirs, tanks, locks, dams and extensions to the canal network).

Representations, uses and practices of these hydraulic systems within the Roman society are transmitted to us by texts. These texts can sometimes be directly related to the construction and the use of these canals as part of treaties (Frontinus, De aquaeductu Urbis Romae) or legislations (Lloris 2006; Arnaud 2008; Chouquer 2008).

\section{Abandonment}

The abandonment phase may be difficult to identify. Again, the anthropogenic view differs from the naturalistic one. Some canals in operation may have found equilibrium in the riverine/marine/palustrine system in which they are included and persist over time. Depending on the canal function, abandonment can be incomplete. For instance, when a navigation canal is partially filled, it can become useless but only for some kind of boats (e.g. Canale Traverso at Portus in Salomon et al. 2012). For drainage ditches and irrigation canals, abandonment may be seasonal, or permanent, and these structures might recover their function under certain conditions (Berger 2008; Bernigaud 2012; Bernigaud et al. in this issue). When changing temporal scale, canal redigging and re-use over previous alignments, several centuries after their abandonment, has also been observed (Berger and Jung 1996).

\section{Who?}

Behind the organization of these hydraulic systems it is obviously possible to foresee the social complexity of the culture that produced them (social hierarchy etc.), and to measure their impact on the social structure and consider the sustainability of a socio-environmental system. However, texts are archives that can tell us about who operated the systems and occupied the territory (continuity of occupation, new settlers), who created the idea or ordered to build canals, who designed, built and maintained these structures (Leveau 1993; Chouquer and Favory 2001). Texts also help clarify the social position and role of each stakeholder involved in the history of the canal (Bruun 1991, 2012). 


\section{Which function for which canal?}

The functions of canals are included in systems which have several meanings, scales and dimensions (symbolic, political, economic, transportation, strategic, etc.).

Canal networks can be related to an urban or rural setting. For the Roman period, there are numerous studies about canal networks for urban purposes. These studies include canals bringing water to cities (including aqueducts), reservoirs, canals for redistribution (including pipes) and sewers (the best known is the Cloaca Maxima at Rome). In rural contexts, studies focus mainly on drainage ditches (Clavel-Lévêque and Hermon 2004) and centuriation systems (Chouquer and Favory 1991; Clavel-Lévêque and Hermon 2004; Brigand 2010). The study of Bernigaud et al. in this issue is particularly interesting since the network he refers to was built out of the great Roman rural development plans and perhaps even inherited from the Iron Age (see also Leveau 2006a). Independently from this rural or urban setting, canals are related to specific water uses such as hydraulic power. We find an illustration in mining contexts with ruina montium (Arbol Moro et al. in this issue) or to feed mills (Leveau 1993, 2006b). Canals can be used to regulate water levels over time, such as drainage (ditches), but also for more specific events such as flood-relief (Keay et al. 2005; Salomon 2013; Testaguzza 1970). Canals can also be used to interconnect inland waterways networks (Rousse 2005; P. Wilson 2012a, b), sea (Gerster 1884; Isserlin et al. 2003) or in-between both (Keay et al. and Salomon et al. in this issue).

Specific attention must be paid to not reduce the canal to a single function. Leveau already suggested, in 1993, that canals in the plain of Arles could have been used for multiple purposes. In some places, the various Roman hydraulic systems (for mining, irrigation, drainage, navigation etc.) seem to have been included in an integrated system. This is well shown in Keay et al. for the Tiber delta and in Arbol Moro et al. for the mines of northwestern Spain. Some texts offer us the opportunity to observe sometimes unavoidable conflicts of interest when water passes through these canals (see the conflict of interest related to water and the presence of canals for the gold mines by the Salassi (Piedmont, Italy), affecting farmers cultivating the downstream plains-Strabo, 4, 6, 7).

Canal function can also have a more symbolic signification, with the aim of elites for instance to distinguish themselves by their possession or their construction for the commonality-i.e. euergetism (Coarelli 2000; Wilson 2012a, b), for policy and tax planning (Chouquer and Favory 2001; Jaillette and Reduzzi Merola 2008), for the conquests and defence of the borders of the Empire as well as along the Rhine limes (navigation canals are often excavated during periods of land conquests-see Uggeri 1997; Kort et al. in this volume) or of course for economic purposes (increasing production and transport facilities).

\section{Research perspectives}

Canals have been the basic structures of many hydraulic civilizations for the last 5 millennia. The Roman civilisation is one of the most illustrious. Diverting water can be a simple local practice requiring little technical and human investments (Leveau 2006a, b; Bernigaud 2012). However, it can also require important works that needed strong support from the Emperor at the time (e.g. Gerster 1884 Johannowsky 1994 on the project of the navigable canal of Nero, which was started but never finished). Despite a few studies such as Berger 2008 for the lower Rhone valley on irrigation canals, drainage ditches etc.; Isserlin et al. in their synthesis published in 2003 focusing on the canal dug by Xerxes 
during his attempt to invade Greece; Bobée et al. 2011 amongst others for the studies concerning aqueducts, canal are rarely studied from an interdisciplinary approach. The papers in this issue will help to spread this type of approach in other geographical areas and contribute to support an integrated spatial and temporal approach of the canals.

Acknowledgments Many thanks to the ANR programs POLTEVERE and PYGMALION, the ERCROMP program, the institution of the Maison de l'Orient et de la Méditerranée, the research group UMR 5600 (Environnement-Ville-Société and the sub-group IRG) and 5133 (Archéorient), the Ecole Doctorale des Sciences Sociales 483 in Lyon, Gwenaëlle Pequay and Anne-Laure Gras for their help in the organisation of the workshop. Many thanks to Penny Copeland for her help in the translation.

\section{References}

Allée P, Lespez L (2006) L'érosion entre société, climat et paléoenvironnement: table ronde en l'honneur du professeur René Neboit-Guilhot. Presses Universitaires Blaise Pascale, Clermont-Ferrand

Arnaud P (2008) Conscience de l'impact environnemental et choix d'aménagements concurrentiels des cours d'eau chez les auteurs anciens. In: Hermon E (ed) Vers une gestion intégrée de l'eau dans l'Empire romain. "L'Erma" di Bretschneider, Rome, pp 157-162

Arnaud-Fassetta G (1998) Dynamiques fluviales holocènes dans le delta du Rhône. Dissertation, Université de Provence (Aix-Marseille 1)

Arnaud-Fassetta G, Landuré C (2003) Hydroclimatic hazards, vulnerability of societies and fluvial risk in the Rhone Delta (Mediterranean France) from the Greek period to the Early Middle Ages. In: Fouache E (ed) The mediterranean world environment and history. Elsevier, Paris, pp 51-76

Ashby T (1935) The aqueducts of Rome. Richmond IA (ed). The Clarendon Press, Oxford

Berger J-F (2000) Les fossés bordiers historiques et l'histoire agraire rhodanienne. Etudes rurales 153(154):59-90

Berger J-F (2008) Etude géo-archéologique des réseaux hydrauliques romains de Gaule Narbonnaise (haute et moyenne vallée du Rhône: apports à la gestion des ressources en eau et à l'histoire agraire antique. In: Hermon E (ed) Vers une gestion intégrée de l'eau dans l'Empire romain, "L'Erma" di Bretschneider, Roma, pp 107-112

Berger J-F, Bravard J-P (2012) Le développement économique romain face à la crise environnementale : le cas de la Gaule narbonnaise. In. In: Berger J-F (ed) Des climats et des hommes. La Découverte-Inrap, Paris, pp 269-289

Berger J-F, Jung C (1996) Fonction, évolution et taphonomie des parcellaires en moyenne vallée du Rhône. Un exemple d'approche intégrée en archéomorphologie et en géoarchéologie. In: Chouquer G (ed) Les formes du paysage 2. Errance, Paris, pp 95-112

Bernigaud N (2012) Les anthroposystèmes des marais de Bourgoin-La-Verpillière (Isère) du néolithique final à l'antiquité tardive (3000 av. J. C. -600 ap. J. -C.: archéologie du paysage et de l'environnement. Dissertation, Université de Nice

Bietak M (1975) Tell el-Dab'a II: Der Fundort im Rahmen einer archäologisch-geographischen Untersuchung über das ägyptische Ostdelta. Verlag der Österreichischen Akademie der Wissenschaften, Vienna

Bobée C, Huon S, Guendon J-L, Salomon J, Gébara C, Michel J-M, Regert M (2011) High-resolution (PIXE) analyses of carbonate deposits in a Roman aqueduct (Fréjus, SE France): implication fort he study of palaeohydrological variability and water resources managment in Southern Gaul during the Roman period. Archaeometry 53(2):241-260

Bravard J-P, Vérot-Bourrely A, Salvador P-G (1992) Le climat d'après les informations fournies par les enregistrements sédimentaires fluviatiles étudiés sur des sites archéologiques. Les Nouvelles de l'Archéologie 50:7-13

Brigand R (2010) Centuriations romaines et dynamique des parcellaires: une approche diachronique des formes rurales et urbaines de la plaine centrale de Venise (Italie). Dissertation, Université de FrancheComté and Università degli Studi di Padova

Bruun C (1991) The water supply of ancient Rome: a study of Roman imperial administration. Societas Scientiarum Fennica, Helsinki

Bruun C (2012) Roman emperors and legislation on public water use in the Roman Empire: clarifications and problems. Water Hist 4:11-33 
Burnouf J, Leveau P (2004) Fleuves et marais, une histoire au croisement de la nature et de la culture: sociétés préindustrielles et milieux fluviaux, lacustres et palustres: pratiques sociales et hydrosystèmes. CTHS, Paris

Carrez-Maratray J-Y (2003) Les branches du Nil d'Hérodote et le désastre athénien de l'île Prosopitis. Comptes rendus des séances de l'Académie des Inscriptions et Belles-Lettres 147:939-954

Chouquer G (2008) L'eau productrice d'héritages : l'exemple de la jurisprudence antique sur l'alluvion. In: Guimier-Sorbets A-M (ed) L'eau, Enjeux, usages et représentations. De Boccard, Paris, pp 171-184

Chouquer G, Favory F (1991) Les Paysages de l'Antiquité. Terres et cadastres de l'Occident romain IVe siècle avant J.-C.-IIIe siècle après J.-C. Errance, Paris

Chouquer G, Favory F (2001) L'arpentage romain. Errance, Paris

Clavel-Lévêque M, Hermon E (2004) Espaces intégrés et ressources naturelles dans l'Empire romain. Presses Universitaires de Franche-Comté, Besançon

Coarelli F (2000) Alcune ipotesi sull'evergetismo imperiale in Italia. In: Cébeillac-Gervasoni M (ed) Les élites municipales de l'Italie péninsulaire de la mort de César à la mort de Domitien entre continuité et rupture. Classes sociales dirigeantes et pouvoir central. Collection de l'Ecole française de Rome 271, Rome, pp 137-148

Frontinus, The Aqueducts of Rome. Translated by Rodgers RH (2004) Frontinus: De aquaeductu urbis Romae. Cambridge University Press, Cambridge

Gerster B (1884) L'isthme de Corinthe: tentatives de percement dans l'antiquité. Bulletin de Correspondance Hellenique 8:225-232

Goiran J-P, Morhange C (2003) Géoarchéologie des ports antiques de Méditerranée: problématiques et études de cas. Topoï 11:645-667

Herodotus, The History. Translated by Grene D (1988) Herodotus: The History. University of Chicago Press, Chicago

Hodge AT (2001) Roman aqueducts and water supply, 2nd edn. Duckworth, London

Isserlin BSJ, Jones RE, Karastathis V (2003) The canal of Xerxes. Summary of investigations 1991-2001. Annu Br Sch Athens 98:369-385

Jaillette P, Reduzzi Merola F (2008) L'eau à usage agricole dans la législation romaine de l'époque tardive : du Code Théodosien au Code Justinien. In: Hermon E (ed) Vers une gestion intégrée de l'eau dans l'Empire romain, "L'Erma" di Bretschneider, Rome, pp 229-241

Johannowsky W (1994) Canali e fiumi per il trasporto del grano. In: Le ravitaillement en blé de Rome et des centres urbains des débuts de la République jusqu'au Haut-Empire. Publications de l'École française de Rome, Naples, pp 159-163

Jorda M (1992) Morphogenèse et fluctuations climatiques dans les Alpes françaises du Sud de l'Age du Bronze au Haut Moyen Age. Nouvelles de l'archéologie 50:14-21

Kamash Z (2012) Irrigation technology, society and environment in the Roman Near East. J Arid Environ $86: 65-74$

Keay S (2013) Rome, Portus and the Mediterranean. Archaeological Monographs of the British School at Rome 21, British School at Rome, Rome

Keay S, Millett M, Paroli L, Strutt K (2005) Portus: an archaeological survey of the Portus of Imperial Rome. Archaeological Monographs of the British School at Rome 15, British School at Rome, London

Leveau P (1993) Arles et les plaines du Bas-Rhône dans l'antiquité. Colonisation militaire romaine et milieu naturel. A propos des moulins de Barbegal et du canal de Marius. Geographia antiqua, Rivista di geografia storica del mondo antico e di storia della geografia 2:51-62

Leveau P (2006a) Innovations romaines et maitrise de la ressource hydraulique dans les Alpes occidentales. Traianus Online: $1-20$

Leveau P (2006b) Les moulins de Barbegal (1986-2006). Traianus Online:1-20

Leveau P (2007) Les zones humides dans les systèmes agraires antiques : le paradigme du "Romain dessicateur" et la gestion romaine des marais. In: Beck C, Benarrous R, Derec J-M, Gallicé A (eds) Les zones humides européennes: espaces productifs d'hier et d'aujourd'hui, AEtuarium 9. Estuarium, Paris, pp 293-308

Lévêque C, Muxart T, Abbadie L, Weill A, Van der Leeuw S (2003) L'anthroposystème: entité structurelle et fonctionnelle des interactions sociétés-milieux. In: Lévêque C, Van der Leeuw S, Reynier I (eds) Quelles natures voulons-nous? Pour une approche socio-écologique du champ de l'environnement. Elsevier, Paris, pp 110-129

Lloris FB (2006) An irrigation decree from Roman Spain: “The Lex Rivi Hiberiensis”. J Roman Stud 96:147-197

Marriner N, Morhange C (2007) Geoscience of ancient Mediterranean harbours. Earth Sci Rev 80:137-194

Mathieu N, Remy B, Leveau P (2011) L'eau dans les Alpes occidentales à l'époque romaine. Cahiers du CRHIPA, Centre de Recherche et d'Histoire de l'Italie et des Pays Alpins 19, Grenoble 
Moore FG (1950) Three canal projects, Roman and Byzantine. Am J Archaeol 54:97-111

Rescanières S (2002) Essai sur le cadre géographique antique du Narbonnais. In: Dellong E (ed) "Carte Archéologique de La Gaule, 11/1. Narbonne et la Narbonnaise". Les éditions de la Maison des sciences de l'homme, Paris, pp 44-51

Rousse C (2005) Salubritas, fossae, portus: exemples de mise en valeur du système fluvial et lagunaire sur le littoral nord-adriatique à l'époque romaine. In Serna V, Gallicé A (eds) La rivière aménagée : entre héritages et modernité. AEtuarium 7, Estuarium, Paris, pp 52-66

Salomon F (2013) Géoarchéologie du delta du Tibre: Evolution géomorphologique holocène et contraintes hydrosédimentaires dans le système Ostie - Portus. Dissertation, Université Lyon 2

Salomon F, Delile H, Goiran J-P, Bravard J-P, Keay S (2012) The Canale di Comunicazione Traverso in Portus: the Roman sea harbour under river influence (Tiber delta, Italy). Géomorphologie: relief, processus, environnement 1(2012):75-90

Stanley DJ, Warne AG (1993) Nile Delta: recent geological evolution and human impact. Science 260:628-634

Strabo, Geography. Translated by Jones HL (1917-1932) Strabo, Geography, vol. 2 (Books 3-4). Loeb Classical Library edition, Harvard University Press, Harvard

Testaguzza O (1970) Portus: illustrazione dei Porti di Claudio e Traiano. Julia Editrice, Rome

Uggeri G (1997) I canali navigabili dell'antico delta padano. In Quilici Gigli S (ed) Uomo, acqua e paesaggio. "L'Erma" di Bretschneider, Rome, pp 55-60

Van der Leeuw S (2002) Placing archaeology at the center of socio-natural studies. Am Antiq 67:597-605

Vigoni A (2006) Il canale interno di Iulia Concordia. Dati storici, archeologici e topografici. In: Morandi Bonacossi D, Rova E, Veronese F, Zanovello P (eds) Tra Oriente e Occidente. Studi in onore di Elena Di Filippo Balestrazzi, SARGON Editrice, Padova, pp 451-468

Wilkinson TJ (2013) Hydraulic landscapes and irrigation systems of Sumer. In: Crawford H (ed) The Sumerian World. Routledge, New York, pp 33-54

Wilson A (2012a) Water, power and culture in the Roman and Byzantine worlds: an introduction. Water Hist 4:1-9

Wilson P (2012b) Waterways, settlements and shifting power in the north-western Nile Delta. Water Hist 4:95-117

Ferréol Salomon is a post-doctoral researcher at the University of Southampton in United-Kingdom. His fields of interest include: (1) landscape reconstruction using palaeo-environmental methods in pluridisciplinary research contexts; (2) geoarchaeology of ancient canals and harbours; (3) fluvial and coastal geomorphology. His fieldwork is located in the Mediterranean area (Italy and Egypt).

Louise Purdue is a post-doctoral researcher at the University of Bonn in Germany. Her work revolves around the geoarchaeological and paleoenvironmental study of water systems in semi-arid, semi-tropical and temperate environments. She is also interested in the evolution of fluvial systems and settlement pattern. She has worked in the American southwest and in Yemen, and her current projects are located in Guatemala and the United Arab Emirates in order to study the diversity of human adaptation and answers in environments where water is scarce.

Jean-Philippe Goiran is a researcher at the CNRS, in Lyon, France. His work focuses on the (1) geoarchaeology of ancient Mediterranean harbors (marine, lagoonal and fluvial), (2) coastal palaeoenvironments and landscape evolution (3) sea level variations (4) human impacts during ancient time. $\mathrm{He}$ develops a new technique based on the use of a mecanical core to extract sedimentary archives trapped in basin harbors. He published several papers on the ancient harbours of Alexandria, Avaris (Egypt); Kition (Cyprus); Portus, Ostia, Cuma (Italy); Piraeus (Athens) in pluridisciplinary contexts and in collaboration with international Institutes/universities.

Jean-Francois Berger is a researcher at the Geographical Research Institute of the Lyon 2 University and the CNRS-UMR 5600. His research interests include geoarchaeological and socio-environmental studies in the Mediterranean basin and Arabia from the Early Neolithic to the Roman Period. He studies Holocene evolution of river paleodynamics and fluvial paleoenvironments, soil processes and erosion, fires regimes, Holocene palaeoclimates and hydraulic systems. He developed projects to understand Societal responses to global environmental changes (RCC) and societal forcing on environments. He has also conducted fieldwork in Southern France, Greece, Bulgaria, Oman, the Emirates and Ouzbekistan since 1992. He is the coresponsible of the " nature-society » thematic at the UMR 5600 since 2012. 